\title{
Combined Effects of Ethylacetate Extracts of Propolis Inducing Cell Death of Human Colorectal Adenocarcinoma Cells
}

Britta Schulz $^{1^{\star}}$, Elizabeth Smith ${ }^{2}$, Richard Funden ${ }^{1}$ and Ulf Moosberger ${ }^{1}$

${ }^{1}$ IFABIR (Institute for Applied Basic Industrial Research), Munich, Germany

${ }^{2}$ Nutrition Research, Bio99 Nutrition Inc, 21709 Himmelpforten, Germany

"Corresponding author: Britta Schulz, IFABIR (Institute for Applied Basic Industrial Research), Munich, Germany, E-mail: b.schulz@ifabir.org

Received date: March 24, 2018; Accepted date: April 03, 2018; Published date: April 24, 2018

\section{Retraction Note}

The article entitled "Combined Effects of Ethylacetate Extracts of Propolis Inducing Cell Death of Human Colorectal Adenocarcinoma Cells" has been accepted for publication in the Journal of Integrative Oncology considering the statements provided in the article as personal opinion of the author which was found not having any conflict or biasness towards anything. As the article was a perspective one, information provided by the author was considered as an opinion to be expressed through publication.

Publisher took decision to make the article online solely based on the reviewers suggestion which considered the article not but a personal opinion of the author. However, it is found that the author have some personal concerns and issues, therefore, being retracted from the journal. 